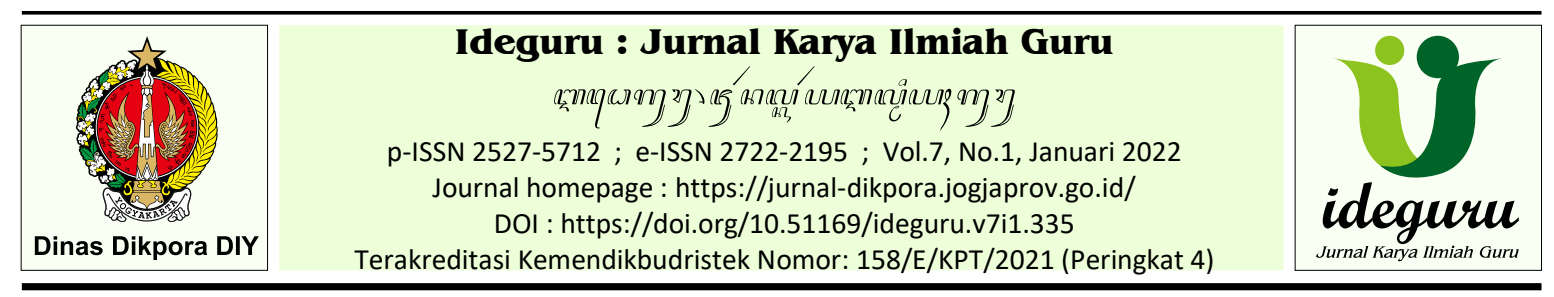

Best Practice - Naskah dikirim: 11/12/2021 - Selesai revisi: 16/12/2021 - Disetujui: 20/12/2021 - Diterbitkan: 01/01/2022

\title{
Penerapan Model Gradual Release of Responsibility dalam Penguatan Pembelajaran Literasi dan Numerasi
}

\author{
Reni Herawati \\ Balai Pendidikan Menengah Kota Yogyakarta, Daerah Istimewa Yogyakarta, Indonesia \\ herawatireni@yahoo.com
}

\begin{abstract}
Abstrak: Best Practice dilakukan berdasarkan urgensi penguatan pembelajaran literasi dan numerasi dengan melibatkan enam sekolah binaan pada SMA di Kota Yogyakarta. Model Gradual Release of Responsibility mengaktualisasikan pelepasan tanggung jawab secara bertahap, meliputi langkah: 1) focused lesson, 2) Guided Instruction, 3) Collaborative Learning, dan 4) Individual Work untuk meningkatkan pemahaman dan keterampilan guru dalam pembelajaran literasi dan numerasi. Analisis data menunjukkan peningkatan pemahaman guru tentang literasi dalam pembelajaran dari 56\% menjadi $69 \%$, atau meningkat $13 \%$. Sementara itu, pemahahaman guru tentang numerasi dalam pembelajaran merangkak dari $36 \%$ menjadi $61 \%$, meningkat $25 \%$. Keterampilan guru dalam menyusun perencanaan pembelajaran literasi mengalami peningkatan sebesar $15 \%$, dari $70 \%$ menjadi $85 \%$. Keterampilan guru dalam perencanaan pembelajaran numerasi mengalami peningkatan tajam sebesar 35\%, dari 38\% menjadi 75\%. Data ini menunjukkan pembimbingan dengan model Gradual Release of Responsibility berdampak signifikan walaupun belum mencapai hasil optimal. Kendala dalam pelaksanaan pembimbingan ditemukan berkaitan dengan terbatasnya waktu akibat bersamaan dengan kegiatan penuntasan vaksin bagi guru dan siswa serta persiapan pembelajaran tatap muka terbatas. Terbatasnya literatur tentang implementasi model Gradual Release of Responsibility dalam kepengawasan sekolah menjadikan hasil dan temuan best practice ini sebagai wawasan baru dan merupakan kebaruan yang sangat bermanfaat baik dalam tataran praktek maupun teori. Selanjutnya direkomendasikan bagi pengawas dan sekolah untuk mengadopsi model Gradual Release of Responsibility baik untuk pembimbingan guru maupun siswa dalam meningkatkan kemampuan literasi dan numerasi.
\end{abstract}

Kata kunci: Model Gradual Release of Responsibility; literasi; numerasi.

\section{The Implementation of the Gradual Release of Responsibility Model in Strengthening Literacy and Numeracy Learning}

\begin{abstract}
This best practice article aimed to analyze and evaluate mentoring with the Gradual Release of Responsibility model for teachers in strengthening literacy and numeracy learning. The mentoring involved six selected senior high schools in Yogyakarta based on the urgency of strengthening literacy and numeracy learning. The Gradual Release of Responsibility model actualized the release of responsibility in stages: 1) Focused Lesson, 2) Guided Instruction, 3) Collaborative Learning, and 4) Individual Work. The data analysis showed teachers' understanding of literacy in learning, from 56\% to 69\%. Meanwhile, teachers' understanding of numeracy in learning crawled from 36\% to 61\%, increasing 25\%. Teachers' skills in planning literacy learning increased by $15 \%$, from $70 \%$ to $85 \%$. Teachers' skills in planning for numeracy lessons experienced a sharp increase of 35\%, from 38\% to $75 \%$. It could be inferred that mentoring with the Gradual Release of Responsibility model had a significant impact, although it did not achieve optimal results. There were some obstacles related to the same time as vaccine completion activities for teachers and students. The limited literature on implementing the Gradual Release of Responsibility model in school supervision put the findings a new insight and a novelty both at the level of practice and research. Furthermore, it is recommended for supervisors and schools to adopt the Gradual Release of Responsibility model for both teacher and student guidance in improving literacy and numeracy skills.

Keywords: Gradual Release of Responsibility Model; literacy; numeracy.
\end{abstract}




\section{Pendahuluan}

Perkembangan pendidikan suatu negara secara umum dapat dilihat dari perkembangan literasi dan numerasi siswa. Dua macam literasi ini merupakan literasi dasar yang harus dikuasai seseorang agar mampu memecahkan masalah dalam kehidupan sehari-hari. Hasil PISA lima belas tahun terakhir ini menunjukkan perkembangan literasi dan numerasi siswa di Indonesia perlu perhatian. Sejak tahun 2010 Gerakan Literasi Sekolah telah digelorakan, diprogramkan, dan dilatihkan namun ternyata implementasi pada masing-masing sekolah masih belum berdampak pada perbaikan literasi dan numerasi siswa (Nugrahanto \& Zuchdi, 2019; Tohir, 2019).

Sejak tahun 2010 guru telah berusaha mengintegrasikan literasi dalam pembelajaran namun sejauh ini masih dalam batas pembiasaan membaca. Pembelajaran literasi dan numerasi telah dilakukan namun hasil wawancara dengan guru menunjukkan implementasi literasi dalam pembelajaran selama ini belum dilakukan melalui analisis kompetensi dasar dan tidak melalui perencanaan yang baik. Guru banyak yang mengaku tidak mengerti bagaimana mengintegrasikan literasi dan numerasi pada pembelajaran.

Selain permasalahan di atas, hasil wawancara menunjukkan masih terdapat miskonsepsi tentang pembelajaran literasi dan numerasi. Sebagian besar guru menganggap literasi merupakan tanggung jawab guru bahasa saja. Sedangkan numerasi merupakan tanggung jawab guru matematika. Mereka menambahkan bahwa guru yang bukan berlatar belakang bahasa kesulitan memberikan penguatan literasi melalui pembelajaran. Demikian juga guru yang berlatar belakang selain matematika mengatakan kesulitan harus belajar matematika.

Permasalahan di atas menjadi pemicu penulis untuk mengadakan pembimbingan bagi guru dalam Penguatan Pembelajaran Literasi Membaca dan Numerasi di SMA Kota Yogyakarta dengan model Gradual Release of Responsibity. Model ini dilakukan dengan pertimbangan dapat memberikan jawaban atas urgensi penguatan pembelajaran literasi dan numerasi. Kendala pandemi COVID-19 menyebabkan pembimbingan secara tatap muka terkendala sehingga pembimbingan dengan model Gradual Release of Responsibility yang dilakukan melalui pelepasan tanggung jawab secara bertahap merupakan pilihan terbaik. Selain itu, alasan utama pemilihan model ini yaitu kesesuaian untuk mengembangkan profil beriman, bertakwa kepada Tuhan YME, dan berakhlak mulia, berkebinekaan global, bergotong royong, mandiri, bernalar kritis, dan kreatif yang guna mewujudkan profil pelajar Pancasila.

Artikel ini menyajikan hasil analisis dan dampak dari pembimbingan pada guru dalam penguatan pembelajaran literasi membaca dan numerasi di SMA Kota Yogyakarta dengan model Gradual Release of Responsibity meliputi aspek: 1) pemahaman guru tentang literasi dalam pembelajaran, 2) pemahaman guru tentang numerasi dalam pembelajaran, 3) keterampilan guru dalam menyusun perencanaan pembelajaran literasi, dan 4) keterampilan guru dalam perencanaan pembelajaran numerasi.

Hasil analisis dan evaluasi menjadi dasar rekomendasi terhadap adopsi model Gradual Release of Responsibility dan memberikan wawasan baru khususnya bagi pengawas sekolah tentang pembimbingan guru dalam penguatan literasi dan numerasi. Langkanya penelitian tentang implementasi model Gradual Release Responsibility dalam konteks kepengawasan menjadikan alasan penulis menganggap temuan dalam best practice ini sebagai suatu kebaruan. Selain itu, pembimbingan guru berkaitan literasi dan numerasi merupakan respon kekinian pengawas sekolah untuk mendongkrak pengetahuan, wawasan, cara pandang, sikap dan perilaku kreatif, kritis, dan inovatif, serta kolaboratif para kepala sekolah dan guru.

\section{Tinjauan Pustaka \\ Gradual Release of Responsibility}

Model ini pertama kali digagas (Pearson \& Gallagher, 1983) kemudian dikembangkan beberapa ahli berikutnya (Fisher, 2008; Fisher \& Frey, 2013, 2021; Turner \& Mitchell, 2019). Artikel ini membahas tentang evaluasi implementasi model Gradual Release of Responsibity merujuk pada teori yang sudah ada, dan dengan penyesuaikan pada kondisi. Model Gradual Release of Responsibity dipilih sebagai upaya perubahan yang ditujukan untuk membantu guru dan kepala sekolah menjadi pencipta dan katalisator, bukan sebagai konsumen kurikulum. Model Gradual Release of Responsibity dilaksanakan berdasarkan keyakinan apabila guru memiliki komitmen mengembangkan kurikulum khususnya pembelajaran berbasis literasi dan numerasi maka pada gilirannya, mereka mampu membimbing guru lain (Au \& Raphael, 2019).

Model Gradual Release of Responsibity lazimnya diaplikasikan oleh guru dan siswa; namun dalam penelitian ini dilakukan dalam konteks pengawas sekolah guru. Gradual Release of Responsibity ini merupakan model yang 
memberikan urutan terstruktur kegiatan secara bertahap mentransfer tanggung jawab dari pengawas kepada para guru (Turner \& Mitchell, 2019). Pelepasan tanggung jawab secara bertahap menggambarkan empat proses, meliputi: 1) focused lesson, 2) guided instruction, 3) collaborative learning, dan 4) independent work (Fisher, 2008; Fisher \& Frey, 2013, 2021).

Gambar 1 memvisualisasikan langkah pembimbingan secara bertahap merujuk model Gradual Release of Responsibity (Fisher \& Frey, 2021) yang dikembangkan oleh peneliti. Tahapan meliputi: 1) Focused Lessons, 2) Guided Instruction, 3) Collaborative Learning, dan 4) Independent Work. Tingkatan tanggung jawab berangsur bergeser dari pengawas kepada subjek pembimbingan meliputi kepala sekolah, wakil kepala sekolah, dan guru.

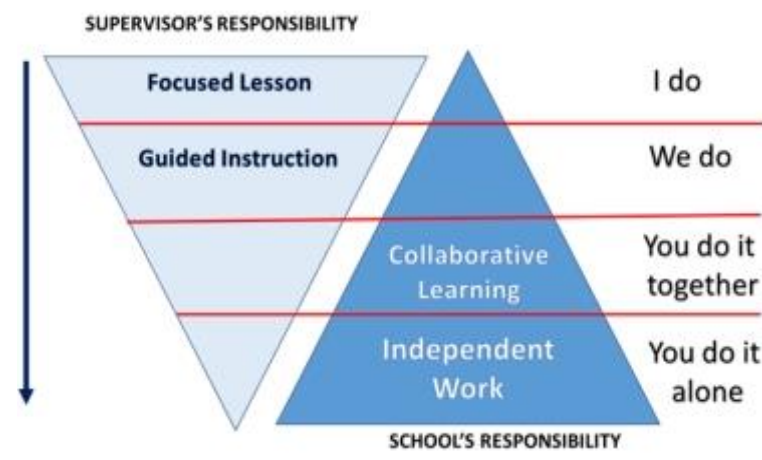

Gambar 1. Model Gradual Release

Responsibility (Fisher \& Frey, 2021) yang

dikembangkan oleh penulis

Dalam tahapan Focused Lesson ini pengawas memodelkan pemikirannya dan pemahaman konten literasi dan numerasi bagi kepala sekolah dan guru. Focused Lesson bertujuan membangun pengetahuan pemahaman tentang literasi numerasi. Pengawas melalui pertemuan virtual dengan zoom meeting memberikan materi literasi dan numerasi secara komprehesif mulai dari komponen literasi, konten teks, kognitif. Selanjutnya dilakukan pemodelan dalam menganalisis komponen literasi di dalam kompetensi dasar. Guru dan kepala sekolah dari 6 sekolah binaan mengikuti secara aktif, mengikuti pembimbingan dan bediskusi merumuskan indikator pencapaian kompetensi, merumuskan tujuan pembelajaran, pengalaman belajar, sumber bacaan, penilaian, refleksi, dan umpan balik. Partisipan yang mengikuti sejumlah 30 orang, dari 6 sekolah, masing-masing terdiri dari kepala sekolah, wakil kepala urusan kurikulum, dan 3 guru.

Tahap Focused Lesson melatih guru dan kepala sekolah berkebinekaan global melalui perubahan dari mind-set tetap menuju mind-set berkembang, menghilangkan miskonsepsi tentang konten-konsep-konteks literasi dan numerasi. Profil bertaqwa kepada Tuhan dan berakhlak mulia diwujudkan dengan pemahaman literasi dan numerasi merupakan kecakapan dasar yang harus dimiliki oleh setiap insan. Bersyukur kepada Tuhan perlu diwujudkan dengan belajar literasi dan numerasi agar dapat mengarungi kehidupan dengan lebih baik dan mampu memecahkan permasalahan dalam kehidupan sehari-hari.

Pada tahap Guided Instruction ini pengawas membimbing guru menyusun rencana pelaksanaan pembelajaran (RPP) berbasis literasi dan numerasi. Masing-masing sekolah memulai dengan menganalisis kompetensi dasar dan menyusun RPP dalam kelompoknya melalui breakout-room. Setelah selesai masing-masing mempresentasikan hasil pekerjaan. Pengawas melakukan pembimbingan dan memberikan arahan untuk perbaikan hasil karya. Partisipan yang mengikuti sejumlah 30 orang, dari 6 sekolah, masing-masing terdiri dari kepala sekolah, wakil kepala urusan kurikulum, dan 3 guru. Tahap ini melatih guru dan kepala sekolah bernalar kritis, berinovasi dan berkreasi, bergotong royong.

Pada tahap Collaborative Learning, pengawas memberikan fasilitasi diskusi melalui Whatsapp Group untuk menghasilkan analisis kompetensi dasar dan RPP yang baik. Kolaborasi antar semua sekolah yang diwakili oleh masingmasing kepala sekolah, waka kurikulum, dan 3 guru menghasilkan rencana pengimbasan kepada semua guru pada semua SMA dan MA di Kota Yogyakarta melalui zoom meeting dengan kapasitas 500 orang. Partisipan yang hadir terdapat 421 orang. Enam sekolah yang merupakan subjek pembimbingan diberikan peran yang seimbang, meliputi: pembawa acara, moderator, penyaji analisis kompetensi dasar dan RPP, Host serta tugas lain dilakukan secara bersama-sama dalam suasana kolaborasi dan gotong royong. Pelaksanaan pengimbasan berjalan dengan lancar dan mendapatkan respon yang sangat baik dari partisipan. Materi dibagikan melalui link google drive sehingga semua bisa mengakses dengan mudah. Kegiatan ini mencakup 40 SMA dan 6 MA se Kota Yogyakarta. Partisipan mengakui bahwa pengimbasan ini sangat bermanfaat karena mendapatkan contoh nyata yang mudah dipahami. Mereka juga berharap kegiatan kolaborasi seperti ini dapat dibudayakan untuk membangun budaya akademik semua guru di Kota Yogyakarta. 
Pada tahap Independent Work semua guru melakukan tugas mengimplementasikan pembelajaran berbasis literasi dan numerasi berdasarkan analisis kompetensi dasar yang dihasilkan. Sejumlah 30 personil, dari 6 sekolah, masing-masing terdiri dari kepala sekolah, wakil kepala urusan kurikulum, dan 3 guru diwajibkan menjadi katalisator yang mengimbaskan dan menggerakan koleganya dalam penguatan pembelajaran berbasis literasi dan numerasi. Tahap ini melatih kepala sekolah dan guru mandiri dengan melaksanakan tanggung jawab melakukan pembelajaran literasi dan numerasi, mengimbaskan kepada guru lain atas inisiasi sendiri, dan melakukan refleksi atas hal yang dilakukan. Langkah pembimbingan secara rinci dijelaskan pada tabel 1 berikut.

Tabel 1. Langkah Pembimbingan dengan Gradual Release of Responsibility

\begin{tabular}{|c|c|c|c|c|}
\hline Peran & Focused Lesson & Guided Instruction & $\begin{array}{l}\text { Collaborative } \\
\text { Learning }\end{array}$ & Independent Work \\
\hline Pengawas & $\begin{array}{l}\text { 1. Mengubah mind-set } \\
\text { 2. Memotivasi } \\
\text { 3. Pemberian materi } \\
\text { 4. Demonstrasi }\end{array}$ & $\begin{array}{l}\text { 1. Mendampingi } \\
\text { 2. Memantau } \\
\text { 3. Memotivasi } \\
\text { 4. Memberikan } \\
\quad \text { feedback } \\
\end{array}$ & $\begin{array}{l}\text { 1. Mendampingi } \\
\text { 2. Memantau } \\
\text { 3. Memotivasi } \\
\text { 4. Memberikan } \\
\text { feedback } \\
\end{array}$ & $\begin{array}{l}\text { 1. Memantau } \\
\text { 2. Memotivasi }\end{array}$ \\
\hline $\begin{array}{l}\text { Kepala } \\
\text { Sekolah, } \\
\text { Waka } \\
\text { Kurikulu } \\
\text { m, dan } \\
\text { Guru }\end{array}$ & $\begin{array}{l}\text { 1. Mengubah mind-set } \\
\text { 2. Menemukan } \\
\quad \text { informasi } \\
\text { 3. Menginterpretasi } \\
\text { 4. Mengintegrasi } \\
\text { 5. Bertanya } \\
\text { 6. Menjawab }\end{array}$ & $\begin{array}{l}\text { 1. Diskusi } \\
\text { 2. Penyusunan } \\
\text { analisis } \\
\text { kompetensi dasar } \\
\text { dan RPP dengan } \\
\text { pembimbingan } \\
\text { 3. Presentasi } \\
\text { 4. Verifikasi }\end{array}$ & $\begin{array}{l}\text { 1. Pengimbahas } \\
\text { an pada } 13 \\
\text { SMA dan } 1 \\
\text { MA } \\
\text { 2. Pengimbasan } \\
\text { pada } 40 \text { SMA } \\
\text { dan } 1 \text { MA }\end{array}$ & $\begin{array}{l}\text { 1. Mengimplemen } \\
\text { tasikan } \\
\text { 2. Mengimbaskan } \\
\text { secara mandiri } \\
\text { dan } \\
\text { berkelanjutan }\end{array}$ \\
\hline $\begin{array}{l}\text { Karakter } \\
\text { (Profil } \\
\text { Pancasila) }\end{array}$ & $\begin{array}{l}\text { 1. Beriman, bertakwa } \\
\text { kepada Tuhan Yang } \\
\text { Maha Esa, dan } \\
\text { Berakhlak Mulia } \\
\text { 2. Bekerbinekaan } \\
\text { Global }\end{array}$ & $\begin{array}{l}\text { 1. Kerjasama } \\
\text { 2. Bernalar kritis } \\
\text { 3. Berinovasi dan } \\
\text { berkreasi }\end{array}$ & $\begin{array}{l}\text { 1. Kerjasama } \\
\text { 2. Bernalar kritis } \\
\text { 3. Berinovasi } \\
\text { dan berkreasi }\end{array}$ & $\begin{array}{l}\text { 1. Mandiri } \\
\text { 2. Tanggung } \\
\text { jawab } \\
\text { 3. Berinovasi dan } \\
\text { berkreasi }\end{array}$ \\
\hline
\end{tabular}

\section{Penguatan Literasi dan Numerasi}

Hasil PISA 2018 menunjukkan 30\% responden memenuhi kompetensi minimum literasi membaca, sedangkan $70 \%$ responden tidak memenuhi kompetensi minimum. Pada literasi matematika diperoleh hasil $29 \%$ responden memenuhi kompetensi minimal, sedangkan $71 \%$ tidak memenuhi. Literasi sains menunjukan hasil terbaik diantara tiga literasi dengan capaian 40\% memenuhi kompetensi minimal (OECD., 2019). Kompetensi minimum literasi membaca merujuk pada tingkat kompetensi minimum adalah tingkat yang menyatakan siswa mampu membaca teks sederhana dan biasa serta memahaminya secara harfiah; menghubungkan beberapa potongan informasi meskipun tanpa petunjuk yang dinyatakan jelas; menarik kesimpulan yang melampaui batasan informasi yang dinyatakan secara jelas; serta menghubungkan teks dengan pengalaman dan pengetahuan pribadi.
Kompetensi minimum literasi matematika adalah tingkat yang menyatakan bahwa siswa dapat menggunakan prosedur rutin, contohnya operasi aritmatika, pada situasi dengan instruksi lengkap; serta menafsirkan dan mengetahui bagaimana sebuah situasi sederhana dapat dipaparkan secara matematis, seperti membandingkan jarak total dua rute yang berbeda atau mengonversi harga dalam mata uang lain. Kompetensi minimum literasi sains adalah tingkat keterampilan yang menyatakan bahwa siswa mampu mengetengahkan pengetahuan tentang isi dan prosedur sains dasar untuk menafsirkan data, mengidentifikasi pertanyaan yang diajukan dalam sebuah eksperimen sederhana, atau mengidentifikasi apakah sebuah kesimpulan bersifat valid menurut data yang tersedia (OECD, 2019).

Melalui hasil tes PISA, para pembuat kebijakan dapat mengukur keterampilan dan pengetahuan siswa di negara mereka dalam perbandingannya dengan siswa di negara-negara 
lain; menetapkan target kebijakan dengan sasaran terukur yang telah dicapai di sistem pendidikan lain; dan belajar dari kebijakan (Kemdikbud, 2018). Hasil analisis pada laporan PISA 2018 menyebutkan masalah utama di Indonesia adalah literasi matematika dan yang membaca.

Literasi membaca didefinisikan sebagai kapasitas individu dalam memahami, menggunakan, merenungkan, dan tercurah secara penuh pada teks tertulis untuk mencapai cita-cita, mengembangkan pengetahuan dan potensi, serta berpartisipasi di dalam masyarakat. Literasi matematika didefinisikan sebagai kapasitas individu untuk merumuskan, menggunakan, dan menafsirkan ilmu matematika pada berbagai macam konteks. Literasi matematika meliputi logika matematika dan penggunaan konsep, prosedur, fakta, dan perangkat matematika untuk menggambarkan, menguraikan, dan memperkirakan sebuah fenomena (Asil \& Brown, 2016; Kemdikbud, 2018; OECD, 2019).

Dalam literasi membaca secara umum siswa mengalami kesulitan dalam menginterpretasikan isi bacaan yang panjang. Responden yang menjawab salah sebagian besar cenderung terkecoh memilih opsi yang eksplisit pada bacaan (Kemdikbud, 2018). Siswa mengalami kesulitan membuat lebih dari satu kesimpulan, perbandingan, dan pembedaan yang harus rinci serta tepat karena menuntut jawaban yang menunjukkan pemahaman komprehensif dan detil atas wacana tunggal atau lebih dari satu wacana. Siswa kesulitan mengolah gagasan yang tidak biasa, atau gagasan yang tidak ditemukan dalam wacana secara tersurat. Siswa memiliki kelemahan dalam mengerjakan soal yang bersifat reflektif dan evaluatif (Mahmud \& Pratiwi, 2019).

Analisis hasil PISA 2018 pada bidang matematika menunjukkan $71 \%$ siswa tidak mampu mengerjakan soal perhitungan aritmatika yang tidak menggunakan bilangan cacah atau soal yang instruksinya tidak gamblang dan terinci dengan baik. Sebagian dari mereka dapat menjawab pertanyaan matematika dalam konteks umum dan informasi yang berkaitan ada dan pertanyaannya sangat jelas. Mereka hanya mampu menggunakan rumus-rumus matematika berdasarkan instruksi langsung dan situasi yang jelas. Dengan demikian dapat diartikan masih banyak siswa Indonesia kesulitan dalam menghadapi situasi yang membutuhkan kemampuan pemecahan masalah menggunakan matematika (OECD., 2019). Hasil analisis di atas serupa dengan hasil wawancara yang dilakukan saat pembimbingan sekolah. Banyak siswa mengeluh akan teks yang panjang yang dijumpai pada latihan Asesmen Kompetensi Minimum. Keluhan tentang soal literasi numerasi antara lain yaitu tidak mampu mengerjakan soal bangun geometri, aljabar, dan ketidakpastian yang instruksinya tidak gamblang dan terinci dengan baik. Keluhan ini sejalan dengan hasil penelitian yang mengatakan kesulitan siswa pada tipe soal masih jarang ditemukan (Fauziah et al., 2021). Dari hasil analisis di atas maka jelas bahwa penguatan pembelajaran literasi dan numerasi sangat urgen dilakukan.

\section{Pembahasan}

Best Practice ini menggunakan pendekatan kualitatif berupa tindakan pembimbingan pengawas kepada guru. Subjek meliputi 6 sekolah dengan 30 personil terdiri dari kepala sekolah, wakil kepala urusan kurikulum, dan 3 guru masing-masing dari SMA Negeri 3 Yogyakarta, SMA Negeri 5 Yogyakarta, SMA Negeri 9 Yogyakarta, SMA Muhammadiyah 1 Yogyakarta, SMA Muhammadiyah 3 Yogyakarta, dan SMA Sang Timur Yogyakarta.

Pembimbingan dengan model Gradual Release of Responsibity dilaksanakan mulai bulan Agustus sampai dengan Oktober 2021. Kegiatan pembimbingan ini bertujuan membantu guru dalam melakukan perencanaan pembelajaran yang mengintegrasikan literasi membaca dan numerasi. Pembimbingan dilakukan secara online dengan fasilitas zoom meeting berkaitan dengan terjadinya pandemi COVID-19. Pertemuan dengan zoom meeting dilakukan lima kali, yaitu tanggal 14 September 2021, 21 September 2021, 23 September 2021, 30 September 2021, 1 Oktober 2021, dan dilengkapi dengan diskusi dan komunikasi sampai akhir Oktober 2021 melalui Whatsapp Group serta sesuai permasalahan masing-masing sekolah.

Data diperoleh dari hasil isian instrumen pengukuran pemahaman terkait penguatan literasi dalam pembelajaran dan pemahaman terkait penguatan numerasi dalam pembelajaran yang dilakukan melalui google form, telaah perencanaan pembelajaran literasi dan numerasi, serta penilaian sikap melalui pengamatan. Teknik analisis data dilakukan dengan menghitung persentase hasil pengukuran pemahaman dan hasil telaah analisis kompetensi dasar dan rencana pelaksanaan pembelajaran (RPP), serta hasil pengamatan sikap. Berdasarkan hasil analisis data kemudian divisualisasikan dalam bentuk diagram yang menunjukkan capaian indikator-indikator yang diukur. Selanjutnya dianalisis sebab akibat serta keterkaitan dengan 
faktor internal dan eksternal. Berdasarkan analisis tersebut disusun kesimpulan dan rekomendasi.

\section{Pemahaman Guru Tentang Penguatan Literasi dalam Pembelajaran}

Pada bagian ini disajikan data yang memberikan informasi tentang pemahaman guru dan kepala sekolah terkait Penguatan literasi dalam pembelajaran serta efektivitas kegiatan pembimbingan dalam membangun pemahaman sekolah tentang konten tersebut. Gambar 2 menyajikan perbandingan capaian pemahaman guru sekolah binaan terkait penguatan literasi dalam pembelajaran di SMA Kota Yogyakarta meliputi:

SMA Negeri 3 Yogyakarta, SMA Negeri 5 Yogyakarta, SMA Negeri 9 Yogyakarta, SMA Muhammadiyah 1 Yogyakarta, SMA Muhammadiyah 3 Yogyakarta, dan SMA Sang Timur Yogyakarta sebelum dan sesudah pembimbingan dengan model Gradual Release of Responsibility. Pengukuran meliputi 5 (lima) indikator: 1) konten literasi, 2) level kognisi dalam literasi, 3) asesmen literasi, 4) tindak lanjut asesmen literasi, dan 5) kemampuan literasi.

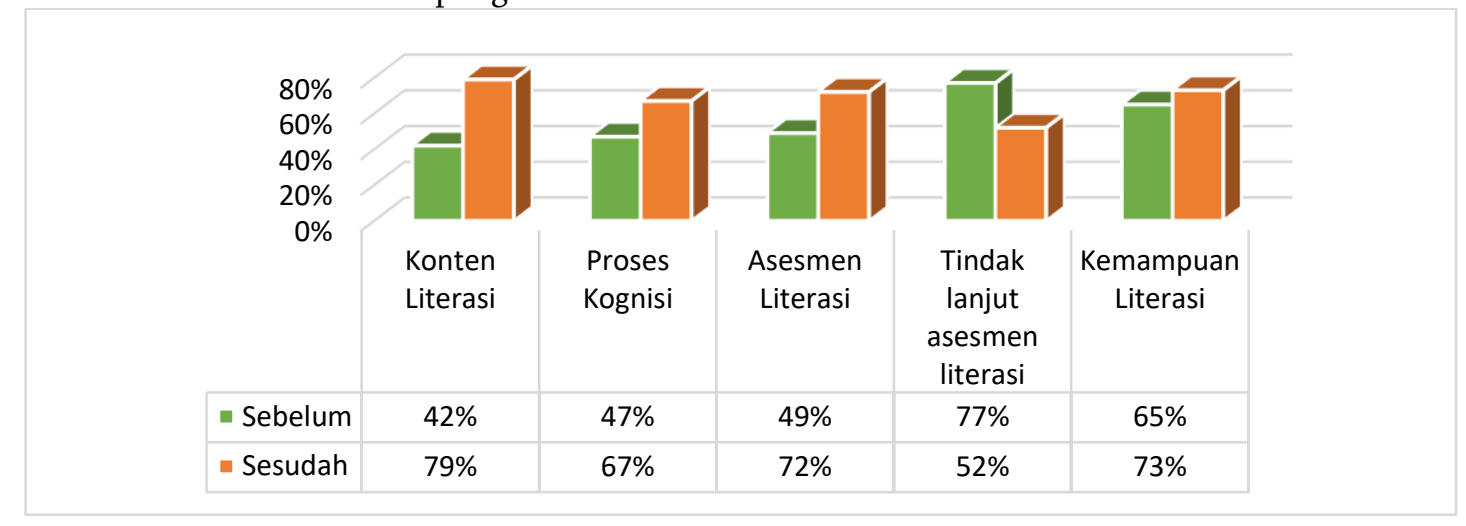

Gambar 2. Diagram Pemahaman Literasi

Gambar 2 di atas menunjukkan gambaran umum tentang kemampuan guru SMA Kota Yogyakarta dalam memahami tentang penguatan literasi ke dalam proses pembelajaran. Visualisasi ini dimaksudkan untuk menunjukkan seberapa besar pengaruh pembimbingan terhadap pemahaman dan kemampuan literasi guru. Pada Gambar 2, terlihat bahwa pemahaman tentang konten literasi setelah pembimbingan dengan model Gradual Release of Responsibility mengalami peningkatan cukup signifikan, yaitu mengalami kenaikan dari semula $42 \%$ menjadi $79 \%$. Indikator yang mengalami kenaikan pada urutan berikutnya adalah pemahaman guru tentang asesmen literasi dengan kenaikan dari $49 \%$ menjadi $72 \%$. Sedangkan untuk indikator pemahaman guru tentang proses kognisi dalam literasi mengalami kenaikan $20 \%$, dari $47 \%$ menjadi $67 \%$. Indikator kemampuan literasi mengalami kenaikan sebesar 8\% dari $65 \%$ menjadi $75 \%$. Hal yang menjadi perhatian yaitu terjadinya penurunan pada indikator tindak lanjut asesmen dari $77 \%$ menjai $52 \%$ atau turun sebesar $25 \%$.

Pemahaman guru berkenaan dengan konten literasi mengalami kenaikan cukup besar ini menunjukkan bahwa pembimbingan model Gradual Release of Responsibility cukup berhasil. Pada awalnya belum begitu memahami tentang konten literasi, tetapi setelah memperoleh pembimbingan menunjukkan pemahaman guru tentang konten literasi membaik. Sedangkan capaian pada indikator pemahaman proses kognisi pada literasi dan asesmen literasi menunjukkan pengaruh pembimbingan tidak begitu besar hasilnya. Hal sebaliknya, terjadi penurunan setelah pembimbingan yaitu pada indikator pemahaman guru tentang tindak lanjut asesmen literasi dan kemampuan literasi guru. Terjadinya penurunan capaian pada pemahaman guru tentang tindak lanjut asesmen literasi maupun pada kemampuan literasi, dikarenakan materi literasi belum begitu dipahami dengan baik, sehingga guru mengerjakan soal pengukuran sebelum pembimbingan hanya secara kira-kira sehingga hasilnya bersifat kebetulan. Pada awal pembimbingan, banyak guru yang mengira literasi merupakan tanggung jawab guru bahasa Indonesia saja. Mereka memiliki miskonsepsi bawa numerasi itu tidak mungkin diberikan oleh guru selain matematika karena akan menyulitkan guru. Mereka lebih mengedepankan kata sulit dan tidak mungkin. Namun setelah dilaksanaan tahap focused lesson, guru mengalami perubahan mind-set.

Kemampuan literasi guru dipengaruhi oleh pemahaman tentang konten literasi, level kognisi dalam literasi, asesmen literasi dan tindak 
lanjutnya. Sedangkan kemampuan guru dalam memahami tindak lanjut asesmen literasi dipengaruhi oleh pemahaman guru tentang program gerakan literasi sekolah dan implementasinya. Dengan demikian dapat disimpulkan bahwa pembimbingan model Gradual Release of Responsibility Penguatan Literasi dalam Pembelajaran cukup efektif.

\section{Pemahaman Guru tentang Penguatan Numerasi dalam Pembelajaran}

Pada bagian ini dijelaskan mengenai data yang diperoleh dari hasil pengukuran pemahaman sebelum dan sesudah pelaksanaan bimbingan dengan model Gradual Release of Responsibity yang dilakukan untuk mendapat informasi tentang pemahaman guru terkait Penguatan numerasi dalam pembelajaran dan efektifitas kegiatan pembimbingan dalam membangun pemahaman guru tentang konten tersebut. Terdapat 5 (lima) indikator yang digali dalam bagian ini, meliputi pemahaman: 1) numerasi, 2) konten numerasi, 3) proses kognisi dalam numerasi, 4) pengelolaan kelas yang memberi penguatan numerasi, dan 5) asesmen numerasi.
Perbedaan hasil sebelum pembimbingan dan sesudah pembimbingan cukup bagus. Hal ini diduga karena pada awalnya guru-guru belum pernah memperoleh materi tentang penguatan numerasi dalam pembelajaran. Selain itu, selama ini sekolah lebih menitikberatkan penguatan literasi membaca. Penguatan numerasi selama ini belum diberikan perhatian yang cukup baik. Pada awal pembimbingan, banyak guru yang mengira numerasi merupakan tanggung jawab guru matematika saja. Mereka memiliki miskonsepsi bawa numerasi itu tidak mungkin diberikan oleh guru selain matematika karena akan menyulitkan guru. Mereka lebih mengedepankan kata sulit dan tidak mungkin. Namun setelah dilaksanakan focused lesson, guru mengalami perubahan mindset. Setelah mendapatkan materi dan pembimbingan, maka guru mengalami peningkatan pemahaman yang signifikan walaupun belum mencapai hasil yang optimal. Namun ada satu indikator yaitu pemahaman tentang asesmen numerasi hanya mencapai peningkatan terkecil. Hal ini karena asesmen numerasi merupakan materi yang kompleks dan belum dikenal sebelum pembimbingan.

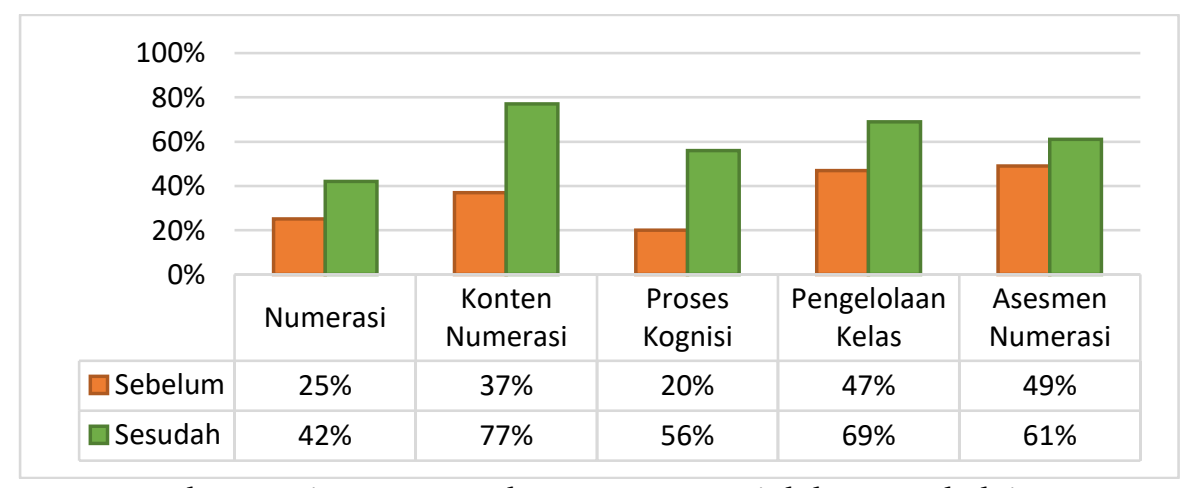

Gambar 3. Diagram Pemahaman Numerasi dalam Pembelajaran

Pemahaman terkait numerasi dalam pembelajaran yang divisualisasikan pada Gambar 3 menunjukkan progress yang bagus. Semua indikator menunjukkan peningkatan cukup baik. Pemahaman tentang numerasi menunjukkan progress dari $25 \%$ menjadi $42 \%$, atau mengalami peningkatan sebesar $17 \%$. Terkait konten numerasi, terdeteksi adanya progress dari $37 \%$ menjadi $77 \%$, atau mengalami peningkatan yang signifikan sebesar $40 \%$. Peningkatan yang kuat terjadi pula pada indikator pemahaman tentang proses kognisi numerasi sebesar 36\% dari $20 \%$ menjadi 56\%. Peningkatan pemahaman tentang pengelolaan kelas mengalami peningkatan sebesar $22 \%$. Sedangkan pemahaman tentang asesmen numerasi mengalami peningkatan kecil, yaitu sebesar $12 \%$.
Dari analisis di atas dapat disimpulkan bahwa pembimbingan pada konten pemahaman Penguatan numerasi dalam pembelajaran mcukup efektif karena terjadi peningkatan pada semua indikator. Meskipun demikian, capaian hasil setelah pembimbingan belum optimal karena materi ini kompleks dan memerlukan waktu yang cukup untuk meningkatkan pemahaman secara komprehensif.

\section{Kemampuan Guru Menyusun Perencanaan Pembelajaran Berbasis Literasi}

Pada bagian ini dijelaskan mengenai data yang diperoleh dari hasil telaah analisis kompetensi dasar dan RPP sebelum dan sesudah pelaksanaan bimbingan dengan model Gradual Release of Responsibity yang dilakukan untuk mendapat 
informasi tentang kemampuan guru dalam menyusun perencanaan pembelajaran berbasis literasi. Gambar 4 menunjukkan diagram Kemampuan Guru Menyusun Perencanaan Pembelajaran Berbasis Literasi. Terdapat 5 (lima) indikator yang digali dalam bagian ini, meliputi keterampilan: 1) Guru memetakan kompetensi dasar (KD) yang akan diajarkan, 2) Guru merumuskan indikator pencapaian kompetensi dan tujuan, 3) Guru menentukan sumber bacaan yang dekat dengan pengalaman peserta didik, 4) Guru merancang pembelajaran dan mengelola kelas, dan 5) Guru menentukan asesmen, refleksi, dan umpan balik.

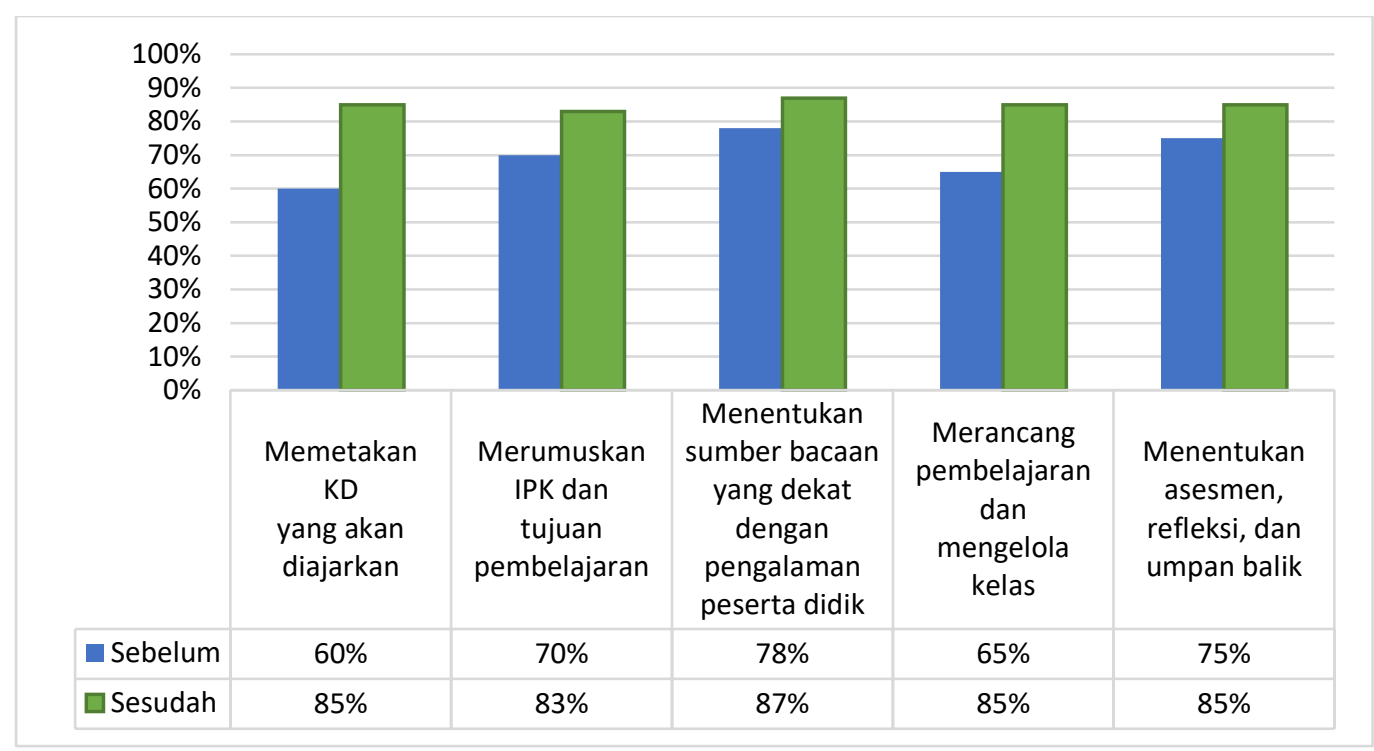

Gambar 4. Kemampuan Guru Menyusun Perencanaan Pembelajaran Berbasis Literasi

Hasil telaah analisis KD dan RPP sebelum dan sesudah pelaksanaan bimbingan dengan model Gradual Release of Responsibity memberikan dampak peningkatan kemampuan guru dalam menyusun perencanana pembelajaran berbasis literasi. Terdapat peningkatan yang sangat signifikan pada 5 (lima) indikator. Keterampilan guru memetakan kompetensi dasar yang akan diajarkan meningkat sebesar 25\%. Hasil wawancara menunjukkan pengakuan guru bahwa selama ini tidak pernah melakukan analisis kompetensi dasar dengan memetakan konten, konteks, dan proses kognisi untuk pembelajaran literasi. Keterampilan guru dalam merumuskan indikator pencapaian kompetensi dan tujuan mengalami peningkatan 13\%. Sedangkankan dalam menentukan sumber bacaan yang dekat dengan pengalaman peserta didik terdapat peningkatan $9 \%$. Rancangan pembelajaran yang dituangkan dalam langkahlangkah pembelajaran menunjukkan keterampilan guru dalam mengelola kelas meningkat sebesar 20\%. Guru semakin terampil menentukan asesmen, refleksi, dan umpan balik, hal ini ditunjukkan dengan adanya peningkatan sebesar $10 \%$.

Data empiris membuktikan dampak pembimbingan dengan model Gradual Release of Responsibility telah membantu guru dalam menyusun perencanaan pembelajaran literasi.
Hasil telaah analisis kompetensi dasar dan RPP sebelum dan sesudah pelaksanaan bimbingan dengan model Gradual Release of Responsibity memberikan gambaran tentang kemampuan guru dalam menyusun perencanana pembelajaran berbasis literasi. Terdapat peningkatan yang sangat signifikan pada 5 (lima) indikator. Keterampilan guru memetakan $\mathrm{KD}$ yang akan diajarkan meningkat sebesar 25\%. Hasil wawancara menunjukkan pengakuan guru bahwa selama ini tidak pernah melakukan analisis kompetensi dasar dengan memetakan konten, konteks, dan proses kognisi untuk pembelajaran literasi. Keterampilan guru dalam merumuskan indikator pencapaian kompetensi dan tujuan mengalami peningkatan $13 \%$. Sedangkan dalam menentukan sumber bacaan yang dekat dengan pengalaman peserta didik terdapat peningkatan 9\%. Rancangan pembelajaran yang dituangkan dalam langkahlangkah pembelajaran menunjukkan keterampilan guru dalam mengelola kelas meningkat sebesar $20 \%$. Guru semakin terampil menentukan asesmen, refleksi, dan umpan balik, hal ini ditunjukkan dengan adanya peningkatan sebesar $10 \%$.

Data empiris membuktikan dampak pembimbingan dengan model Gradual Release of Responsibility telah membantu guru dalam melatih keterampilan menyusun perencanaan 
pembelajaran berbasis literasi. Meskipun hasil belum optimal, namun perbandingan antara sebelum dan sesudah pembimbingan sangat signifikan. Dengan demikian dapat disimpulkan pembimbingan efektif dan berdampak pada peningkatan keterampilan guru.

\section{Kemampuan Guru Menyusun Perencanaan Pembelajaran Berbasis Numerasi}

Data yang diperoleh dari hasil telaah analisis kompetensi dasar dan RPP sebelum dan sesudah pelaksanaan bimbingan dengan model Gradual Release of Responsibity yang dilakukan untuk mendapat informasi tentang kemampuan guru dalam menyusun perencanaan pembelajaran berbasis numerasi ditampilkan pada Gambar 5 . Seperti pada pembelajaran literasi, pada perencanaan pembelajaran numerasi juga terdapat 5 (lima) indikator yang digali dalam bagian ini, meliputi keterampilan: 1) Guru memetakan KD yang akan diajarkan, 2) Guru merumuskan indikator pencapaian kompetensi dan tujuan, 3) Guru menentukan sumber bacaan yang dekat dengan pengalaman peserta didik, 4) Guru merancang pembelajaran dan mengelola kelas, dan 5) Guru menentukan asesmen, refleksi, dan umpan balik.

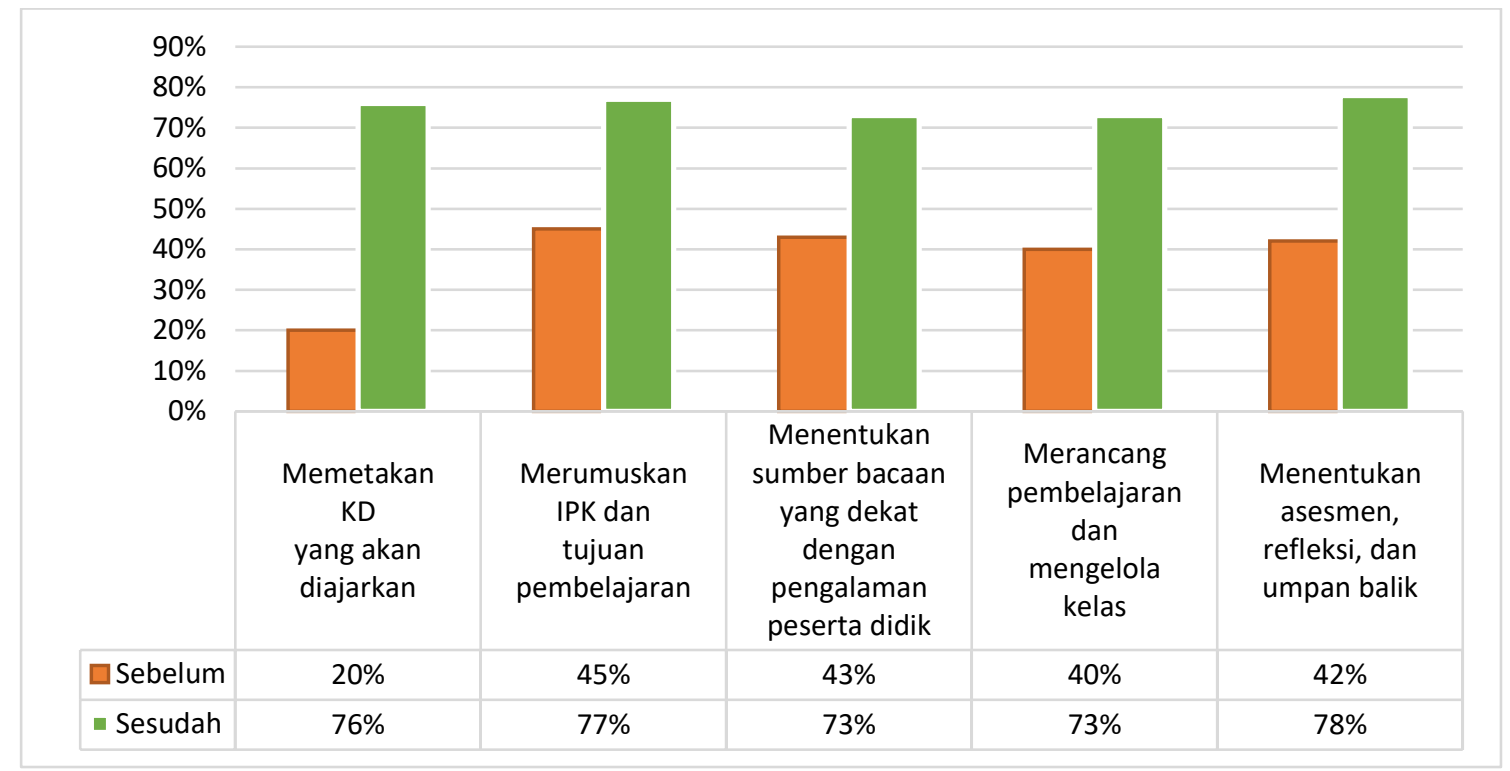

Gambar 5. Kemampuan Guru dalam Menyusun Perencanaan Pembelajaran Berbasis Numerasi

Data empiris membuktikan dampak pembimbingan dengan model Gradual Release of Responsibility telah membantu guru dalam melatih keterampilan menyusun perencanaan pembelajaran berbasis numerasi. Meskipun hasil belum optimal namun perbandingan antara sebelum dan sesudah pembimbingan sangat signifikan. Dengan demikian dapat disimpulkan pembimbingan efektif dan berdampak pada peningkatan keterampilan guru. Hasil wawancara menguatkan informasi bahwa guru menjadi paham dan bisa menyusun RPP berbasis numerasi. Materi numerasi merupakan hal baru yang tidak pernah dipelajari sebelumnya. Hasil ini menunjukkan pembimbingan dengan model Gradual Release of Responsibilty memberikan dampak baik bagi kompetensi guru dalam menyusun perencanaan pembelajaran numerasi. Hasil pembahasan ini senada dengan temuan sebelumnya yang menyebutkan pemberian tanggung jawab secara bertahap pada siswa akan memberikan rasa memiliki dan komitmen dalam berliterasi (Fisher \& Frey, 2021). Pembimbingan ini memiliki perbedaan pada subjeknya, bukan siswa namun guru. Penelitian Gradual Release of Responsibility pada pelatihan guru telah membuktikan efektif karena tahapan-tahapan pelepasan tanggung jawab menjadi terstruktur dan mudah dilakukan (Clark, 2014).

\section{Simpulan dan Saran}

Sesuai dengan tujuan pembimbingan, dapat disimpulkan: 1) pembimbingan model Gradual Release of Responsibility dalam penguatan literasi dalam pembelajaran cukup efektif dengan perkembangan pemahaman guru tentang literasi dalam pembelajaran dari $56 \%$ menjadi $69 \%$, atau peningkatan 13\%; 2) pembimbingan model Gradual Release of Responsibility dalam penguatan numerasi pembelajaran efektif karena terjadi peningkatan pada semua indikator. Capaian hasil setelah pembimbingan belum optimal yaitu dari $36 \%$ menjadi $61 \%$, atau meningkat $25 \%$. Hal ini karena materi bersifat 
kompleks dan memerlukan waktu yang cukup untuk meningkatkan pemahaman secara komprehensif; 3) pembimbingan dengan model Gradual Release of Responsibility telah membantu guru dalam meningkatkan keterampilan menyusun perencanaan pembelajaran berbasis literasi. Meskipun hasil belum optimal namun perbandingan antara sebelum dan sesudah pembimbingan sangat signifikan. Dengan demikian dapat disimpulkan pembimbingan efektif dan berdampak pada peningkatan keterampilan guru sebesar 15\%, dari $70 \%$ menjadi $85 \%$; 4) pembimbingan dengan model Gradual Release of Responsibility memberikan dampak baik bagi kompetensi guru dalam menyusun perencanaan pembelajaran numerasi. Keterampilan guru dalam perencanaan pembelajaran numerasi mengalami peningkatan tajam sebesar $35 \%$, dari $38 \%$ menjadi $75 \%$.

Hasil implementasi model Gradual Release Responsibility dalam konteks kepengawasan ini merupakan temuan yang layak diadopsi oleh pengawas lain dalam pembimbingan guru berkaitan literasi dan numerasi. Gradual Release Responsibility dapat dipilih sebagai respon kekinian pengawas sekolah untuk mendongkrak pengetahuan, wawasan, cara pandang, sikap dan perilaku kreatif, kritis, dan inovatif, serta kolaboratif pengawas, kepala sekolah, maupun guru.

Berdasarkan kesimpulan di atas maka untuk meningkatkan keberhasilan penguatan literasi dalam pembelajaran, sekolah perlu bekerjasama dengan pengawas sekolah memfasilitasi pembimbingan dengan model Gradual Release of responsibility dalam penguatan pembelajaran literasi dan numerasi. Pelaksanaan pembimbingan sebaiknya memilih waktu yang tepat dan dengan durasi yang cukup, agar pembimbingan lebih berhasil.

Best Practice ini memiliki keterbatasan karena hanya melibatkan 6 sekolah binaan dengan jumlah subjek yang terbatas pula. Oleh karena itu disarankan bagi pengawas agar selanjutnya untuk menguji efektivitas model Gradual Release of Responsibility dalam scope yang lebih luas dan melibatkan responden atau subjek yang lebih banyak.

\section{Daftar Pustaka}

Asil, M., \& Brown, G. T. (2016). Comparing OECD PISA reading in English to other languages: Identifying potential sources of noninvariance. International Journal of Testing, 16(1), 71-93. Doi: https://doi.org/10.1080/15305058.2015.1 064431
Au, K. H., \& Raphael, T. E. (2019). Sustainable school improvement: The gradual release of responsibility in school change. In The gradual release of responsibility in literacy research and practice: Emerald Publishing Limited.

Clark, S. (2014). Avoiding the Blank Stare: Teacher Training with the Gradual Release of Responsibility in Mind. Paper presented at the English Teaching Forum.

Fauziah, A., Sobari, E. F. D., \& Robandi, B. (2021). Analisis Pemahaman Guru Sekolah Menengah Pertama (SMP) Mengenai Asesmen Kompetensi Minimum (AKM). Edukatif: Jurnal Ilmu Pendidikan, 3(4), 1550-1558.

Fisher, D. (2008). Effective Use of The Gradual Release of Responsibility Model. Author Monographs, 1-4.

Fisher, D., \& Frey, N. (2013). Better learning through structured teaching: A framework for the gradual release of responsibility: ASCD.

Fisher, D., \& Frey, N. (2021). Better learning through structured teaching: A framework for the gradual release of responsibility: ASCD.

Kemdikbud. (2018). Pendidikan di Indonesia: Belajar dari PISA 2018. Jakarta: Kemdikbud.

Mahmud, M. R., \& Pratiwi, I. M. (2019). Literasi numerasi siswa dalam pemecahan masalah tidak terstruktur. Kalamatika: Jurnal Pendidikan Matematika, 4(1), 69-88. doi: https://doi.org/10.22236/KALAMATIKA.vo 14no1.2019pp69-88

Nugrahanto, S., \& Zuchdi, D. (2019). Indonesia PISA result and impact on the reading learning program in Indonesia. Paper presented at the International Conference on Interdisciplinary Language, Literature and Education (ICILLE 2018).

OECD. (2019). PISA Assessment and Analytical Framework: Mathematics, Reading, Science, Problem Solving and Financial Literacy. doi:https://doi.org/10.1787/19963777

Pearson, P. D., \& Gallagher, M. C. (1983). The instruction of reading comprehension. Contemporary educational psychology, 8(3), 317-344.

Doi: https://doi.org/10.1016/0361476X(83)90019-X

Tohir, M. (2019). Hasil PISA Indonesia tahun 2018 turun dibanding tahun 2015. Doi: https://doi.org/10.17605/OSF.IO/8Q9VY

Turner, J. D., \& Mitchell, C. (2019). Sustaining culture, expanding literacies: culturally relevant literacy pedagogy and gradual release of responsibility. In The Gradual Release of Responsibility in Literacy Research and Practice: Emerald Publishing Limited. 